Review

\title{
Psidium cattleianum fruits: A review on its composition and bioactivity
}

\author{
Elisa dos Santos Pereira ${ }^{\mathrm{a}, \mathrm{b}}$, Juliana Vinholes ${ }^{\mathrm{a}, *}$, Rodrigo C. Franzon ${ }^{\mathrm{a}}$, Gabriel Dalmazo ${ }^{\mathrm{b}}$, \\ Márcia Vizzotto ${ }^{\mathrm{a}, *}$, Leonardo Nora ${ }^{\mathrm{b}}$ \\ ${ }^{a}$ Embrapa Clima Temperado, BR 392, KM 78, C. P. 403, CEP 96010-971 Pelotas, RS, Brazil \\ ${ }^{\mathrm{b}}$ Departamento de Ciência e Tecnologia Agroindustrial, Faculdade de Agronomia Eliseu Maciel, Universidade Federal de Pelotas, Avenida Eliseu Maciel, S/N, CEP \\ 96160-000 Capão do Leão, RS, Brazil
}

\section{A R T I C L E I N F O}

\section{Keywords:}

Araçá

Chemical composition

Antioxidant

Antidiabetic

Anticancer

Antimicrobial

Anti-inflammatory

Anti-aging

\begin{abstract}
A B S T R A C T
Psidium cattleianum Sabine, commonly known as araçá, is a Brazilian native fruit, which is very juicy, with sweet to sub acid pulp and a spicy touch. The fruit can be eaten fresh or processed into juice, jellies and ice creams. Araçás are source of vitamin C, minerals, fatty acids, polysaccharides, volatile compounds, carotenoids and phenolic compounds, which can provide nutrients and phytochemical agents with different biological functions. Different pharmacological studies demonstrate that $P$. cattleianum exerts antioxidant, antidiabetic, anticarcinogenic, antimicrobial, anti-inflammatory and antiaging effects. Thus, this article aims to review the chemical composition and biological effects reported for araçá fruit in the last years.
\end{abstract}

\section{Introduction}

Psidium cattleianum Sabine (Myrtaceae) is a Brazilian native species that can be found from Bahia to Rio Grande do Sul states, and also in the neighbor country Uruguay. It has adapted very well in tropical climates as Hawaii and many Caribbean islands (Galho et al., 2007; Patel, 2012). The species is characterized as a small fructiferous evergreen tree/shrub (1-4 $\mathrm{m}$ high) whose fruit diameters are between $2.2 \mathrm{~cm}$ and $5 \mathrm{~cm}$, with ovoid or oblong shape, weighting less than $20 \mathrm{~g}$, with high number of seeds (Biegelmeyer et al., 2011; Castro et al., 2004). Fig. 1 shows the most common varieties of $P$. cattleianum fruits presenting yellow and red epicarp and cream or white endocarp. However, there are also fruits with red epicarp and endocarp (Castro et al., 2004), but they are more rare. According to the morphological prospection of 40 accessions of Psidium spp. (araçá) from different Brazilian ecoregions, $80 \%$ of fruits have cream endocarp, $11 \%$ white and $9 \%$ pale red endocarp (Santos et al., 2010). Despite the color differences among $P$. cattleianum fruits varieties, they are characterized by a juicy core, with a translucent pulp filled with seeds.

Relevant synonyms for this species are Psidium littorale Raddi, Eugenia ferruginea Sieber ex C. Presl, Guajava obovata (Mart. ex DC.) Kuntze, $P$. ferrugineum C. Presl, P. indicum Bojer, P. obovatum Mart. ex DC., P. variabile O. Berg and G. cattleiana (Afzel. ex Sabine) Kuntze. Nevertheless, fruits are popular known in Brazil as araçá, araçáamarelo, araçá-vermelho, araçá-rosa, araçá-de-comer, araçá-da-praia, araçá-de-coroa or araçá-do-campo and in other countries are known as Cattley guava, Chinese guava, purple guava, yellow strawberry guava, red strawberry guava, guayaba, cherry guava and lemon guava (Bezerra, Lederman, Silva Junior, \& Proença, 2010; Lisbôa, Kinupp, \& de Barros, 2011; Mitra, Irenaeus, Gurung, \& Pathak, 2012).

Flowering in south of Brazil occurs in two main times, the first from September to October and the second in December. Eventually, a third flowering can occur in March, thus araçás can be harvest from October to March (Raseira and Raseira, 1996). Under specific conditions, araçá orchard ( $0.5 \mathrm{~m}$ between plants and $4.0 \mathrm{~m}$ between rows of plants) can produce 10 ton of fruit per ha, considering $2 \mathrm{~kg}$ of fruit per plant (Franzon et al., 2009).

Araçá is very juicy fruit, with an excellent flavor and a sweet to sub acid pulp, with a spicy touch (Biegelmeyer et al., 2011). The fruit, consumed in natura or processed (sweets, jams and juices), has high potential to the agri-food sector (Reissig, Vergara, Franzon, Rodrigues, \& Chim, 2016; Santos et al., 2007). Moreover, due to the bioactivity (antiproliferative, antidiabetic and antimicrobial) of the fruit extract, which may be related to high content of vitamin $\mathrm{C}$ and antioxidants, the araçá can also be valuable to the pharmaceutical industry (Franzon et al., 2009; Medina et al., 2011)

The bioactivity reported for araçá is mainly attributed to the high content of phenolic compounds, which are well known secondary metabolites with high antioxidant capacity. These compounds are able to protect biological systems against the excess of free radicals and

\footnotetext{
* Corresponding authors.

E-mail addresses: julianarochavinholes@gmail.com (J. Vinholes), marcia.vizzotto@embrapa.br (M. Vizzotto).
} 


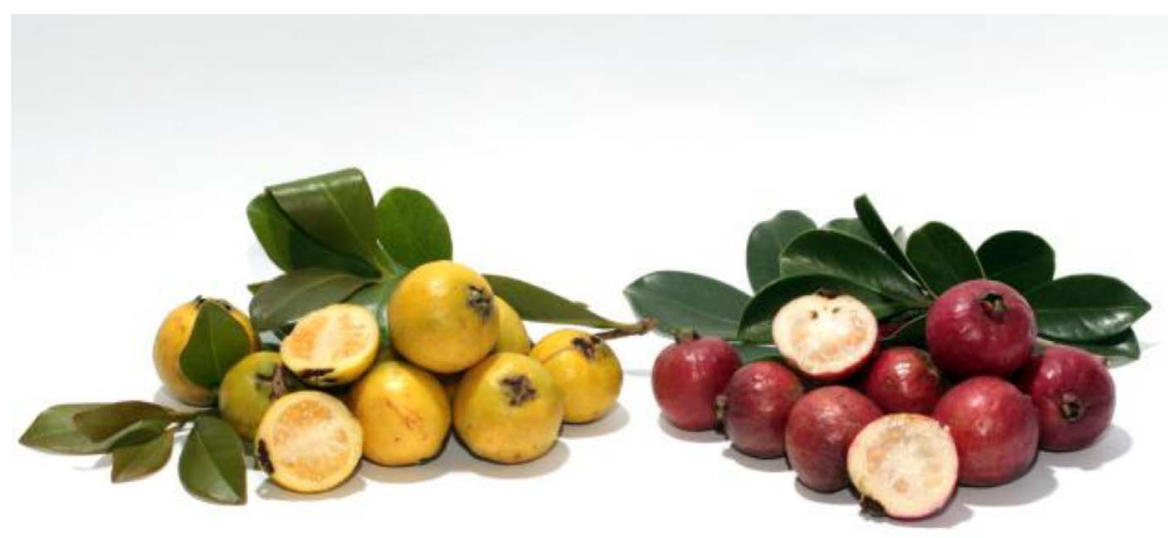

Fig. 1. Yellow and red araçás (from: Paulo Luiz Lanzetta Aguiar).

reactive oxygen species (Verma, Rajkumar, Banerjee, Biswas, \& Das, 2013). Thus, when included in human diet they contribute to reduce the development of degenerative diseases such as atherosclerosis, cancer, cardiovascular diseases, diabetes among others. In addition, araçá also contains other interesting chemical compounds such as minerals, fatty acids, sugars, volatile compounds and carotenoids that can also contribute to human health.

Prospective applications in the agri-food sector and pharmaceutical industry has been reviewed by Patel (2012). Since then several studies have been conducted, providing knowledge to subsidize other applications for this species. Thus, the aim of this article was to review the literature on the biological activities and chemical composition reported for yellow and red araçá fruit in the last years.

\section{Chemical composition}

\subsection{Araçá nutritional composition}

In $100 \mathrm{~g}$ of araçá fresh fruit there are $81.73-84.9 \mathrm{~g}$ of water, $0.75-1.03 \mathrm{~g}$ of protein, $0.63-1.50 \mathrm{~g}$ of minerals, $4.32-10.01 \mathrm{~g}$ of carbohydrate, $0.42-0.55 \mathrm{~g}$ of lipid, $3.87-6.14 \mathrm{~g}$ of fiber and $26.8 \mathrm{kcal}$ of energy (Morton, 1987). When compared with apple, the most common fruit consumed worldwide, araçá is less caloric, lower in carbohydrate content, and higher in lipid and dietary fiber content.

Protein content in araçá was reported to decrease in function of fruit maturation (Galho et al. 2007). Levels of protein were $93.6 \mathrm{mg} / \mathrm{g}$ and $39.8 \mathrm{mg} / \mathrm{g}$ dry basis, 10 and 122 days after anthesis, respectively. Fact explained since young fruits, normally presents higher proportions of protoplasm in relation to dry matter Galho et al. (2007). In respect to araçá amino acids composition, there are $382 \mathrm{mg}$ of total amino acids and $154 \mathrm{mg}$ of essential amino acids in $100 \mathrm{~g}$ of araçá (Hall, Smoot, Knight, \& Nagy, 1980). Essential and non-essential amino acids present in araçás are shown in Fig. 2. Leucine is the major essential amino acid followed by lysine and tyrosine, isoleucine and valine while the others are present in smaller amounts (Fig. 2) (Hall et al., 1980). Glutamine is the main non-essential amino acid followed by asparagine, alanine, glycine, proline, serine, arginine and hydroxyproline (Fig. 2) (Hall et al., 1980). The recommended intake of proteins is $0.8 \mathrm{~g} / \mathrm{kg} /$ day for an adult (19-70 years old) according to the Dietary Reference Intakes. Although the araçá consumption provides a small contribution on the recommended intake of proteins, it can afford relevant amounts of leucine that is the most required amino acid $(42 \mathrm{mg} / \mathrm{kg} /$ day).

Amino acids are important compounds for the normal human body function. These compounds act on cellular signaling, and are regulators of gene expression and the protein phosphorylation cascade. Besides, amino acids are fundamental precursors for the syntheses of other extremely important compounds such as hormones and low molecular weight nitrogenous substances (Wu, 2009).

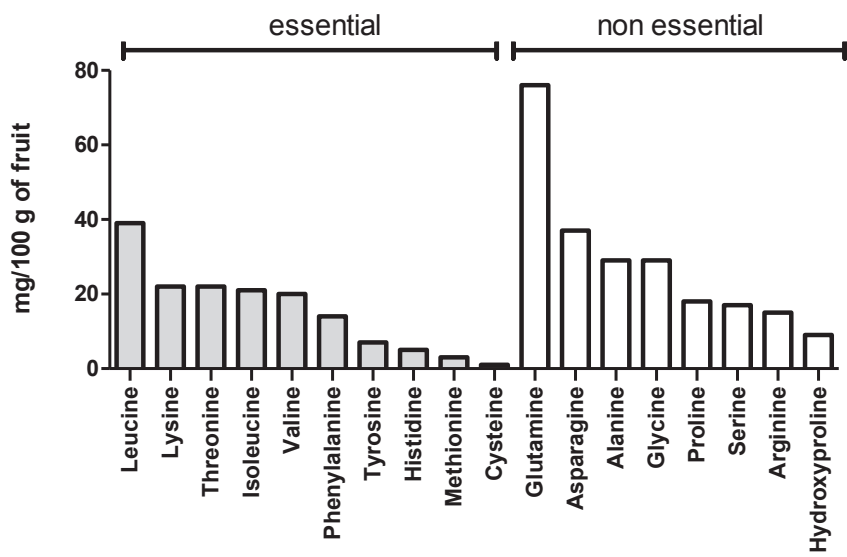

Fig. 2. Essential and non-essential amino acids present in araçá.

Different groups of researchers studied the mineral composition of mature and immature yellow araçás (Table 1). Araçá from Hawaii, regardless the maturation stage, was rich in macrominerals such as potassium (1.30-1.59\%) and nitrogen (0.85-0.91\%), and microminerals such as iron $(0.0016-0.0043 \%)$ and zinc $(0.0011-0.0050 \%)$ (Adrian, Arancon, Mathews, \& Carpenter, 2015). Similar results were obtained for yellow and red mature araçá in Brazil (Kinupp and Inchausti, 2008; Silva, Santos, Mendes, \& Martins, 2008). Minerals are involved in metabolic process and they have exclusive physiological function in the regulation and catalyzation of important cellular mechanisms (Bailey, West, \& Black, 2015).

Araçá seed contains linoleic acid as the major fatty acid in both yellow and red varieties, with $61.01 \% \pm 2.51 \%$ and $75.42 \% \pm 3.50 \%$, respectively. Oleic acid is present in higher amount in the yellow genotype (YG) $(14.99 \% \pm 0.88 \%)$ than in red genotype (RG) $(10.83 \% \pm 0.99 \%)$. Quantitative differences for palmitic acid where observed among YG and RG, where the yellow one has $19.92 \% \pm 0.26 \%$, more than double the percentage observed in the red one $(9.12 \% \pm 2.12 \%)$. The content of stearic acid was low in both genotypes, $3.57 \% \pm 0.62 \%$ in the yellow and $4.63 \% \pm 0.40 \%$ in the red one (Biegelmeyer et al., 2011). The lipid profile evaluation has become an important parameter since the fatty acids are crucial for the maintenance of a normal physiological health. Moreover, diets rich in mono and polyunsaturated fatty acids are associated with lower risk of development of cardiovascular diseases and atherosclerosis. For instance, linoleic acid, the most representative in araçá, exerts health benefits such as antimutagenic, anticarcinogenic (breast and skin cancers), thermogenic, antidiabetic, preventive of atherosclerosis, antihypertensive, and stimulant of the immunological system (Koba and Yanagita, 2014). 
Table 1

Mineral composition of mature and immature yellow araçá and mature red araçá.

\begin{tabular}{|c|c|c|c|c|}
\hline \multirow[t]{2}{*}{ Minerals } & \multicolumn{2}{|l|}{ Yellow araçá } & \multirow{2}{*}{$\begin{array}{l}\text { Red araçá } \\
\text { Mature }\end{array}$} & \multirow[t]{2}{*}{ References } \\
\hline & Mature & Immature & & \\
\hline \multicolumn{5}{|c|}{ Macrominerals (\%) } \\
\hline $\mathrm{Ca}$ & $0.14-0.21$ & 0.15 & 0.18 & Adrian et al. (2015), Kinupp and Inchausti (2008), Silva et al. (2008) \\
\hline $\mathrm{Mg}$ & 0.11 & 0.12 & 0.08 & Adrian et al. (2015), Kinupp and Inchausti (2008) \\
\hline $\mathrm{N}$ & 0.85 & 0.91 & - & Adrian et al. (2015) \\
\hline $\mathrm{P}$ & 0.12 & 0.12 & 0.11 & Adrian et al. (2015), Kinupp and Inchausti (2008) \\
\hline K & 1.52 & 1.59 & 1.30 & Adrian et al. (2015), Kinupp and Inchausti (2008) \\
\hline S & 0.07 & 0.07 & 0.06 & Adrian et al. (2015), Kinupp and Inchausti (2008) \\
\hline $\mathrm{Na}$ & 0.20 & 0.21 & 0.05 & Adrian et al. (2015), Kinupp and Inchausti (2008) \\
\hline \multicolumn{5}{|c|}{ Microminerals (\%) } \\
\hline B & 0.0012 & 0.0012 & 0.0011 & Adrian et al. (2015), Kinupp and Inchausti (2008) \\
\hline $\mathrm{Cu}$ & 0.0011 & 0.0008 & 0.0006 & Adrian et al. (2015), Kinupp and Inchausti (2008) \\
\hline $\mathrm{Fe}$ & $0.0021-0.0039$ & 0.0043 & 0.0016 & Adrian et al. (2015), Kinupp and Inchausti (2008), Silva et al. (2008) \\
\hline Mn & 0.0018 & 0.0011 & 0.0018 & Adrian et al. (2015), Kinupp and Inchausti (2008) \\
\hline $\mathrm{Ni}$ & 0.0001 & 0.0001 & - & Adrian et al. (2015) \\
\hline $\mathrm{Zn}$ & $0.0011-0.0050$ & 0.0011 & 0.0015 & Adrian et al. (2015), Kinupp and Inchausti (2008) \\
\hline
\end{tabular}

The contents of starch, soluble carbohydrates and reducing sugars were reported to increase along araçá fruit maturation. At day 122 (mature stage) concentrations of $89.2,105.7$ and $26.0 \mathrm{mg} / \mathrm{g}$ dry basis were find for starch, soluble carbohydrates and reducing sugars, respectively (Galho et al., 2007). Non soluble carbohydrates, represented by cellulose, hemicellulose and lignin, were also evaluated by Galho et al. (2007). Contents of hemicellulose (day 10 after anthesis $=16.3 \mathrm{mg} / \mathrm{g}$ dry basis; mature stage day $122=9.7 \mathrm{mg} / \mathrm{g}$ dry basis) and lignin (day 10 after anthesis $=18.4 \mathrm{mg} / \mathrm{g}$ dry basis; mature stage day $122=2.8 \mathrm{mg} / \mathrm{g}$ dry basis) decreased along fruit maturation, while cellulose do not changed $(23.4 \mathrm{mg} / \mathrm{g}$ dry basis at day 10 after and $25.3 \mathrm{mg} / \mathrm{g}$ dry basis at mature stage day 122) (Galho et al., 2007). Total dietary fiber, insoluble fiber, carbohydrates, total sugar and reducing sugar contents reported by Pereira et al. (2012) for yellow genotype was $11.95 \mathrm{~g}, 11.55 \mathrm{~g}, 15.08 \mathrm{~g}, 22.74 \mathrm{~g}$ and $18.6 \mathrm{~g} / 100 \mathrm{~g}$ of dry matter, respectively. In addition, different pectin and hemicellulose compounds were found in the edible portion of the araçá fruit (mesocarp) (Vriesmann, Lúcia, Petkowicz, \& Borba, 2009).

The increased consumption of alimentary fibers can contribute in the reduction of chronic diseases such as diabetes, cardiovascular diseases and colon neoplasia (Bernaud and Rodrigues, 2013; Hur, Kim, Choi, \& Lee, 2013; Sriamornsak, 2003). In the human diet, pectin is considered a dietary fiber. Different studies suggest that pectin ingestion can reduce cholesterol and triglycerides levels, arterial tension and also can reduce glucose absorption. Additionally, pectin monomers, resulted from the microbial degradation of pectin in human intestine, was described with prebiotic effect (Nazzaro, Fratianni, Orlando, \& Coppola, 2012).

\subsection{Phytochemicals}

\subsubsection{Vitamin $C$}

Vitamin C, or ascorbic acid, has many physiological functions. The two most important ones are its role on the increase of absorption of iron from vegetal origin and its high antioxidant activity, protecting the cell membranes and lipoproteins against the lipid peroxidation (Figueroa-Méndez and Rivas-Arancibia, 2015). Araçá is known as a rich source of vitamin C, with values of $200 \mathrm{mg}$ and $242 \mathrm{mg}$ per gram of fresh fruit, for red genotype and yellow genotype, respectively (Luximon-Ramma, Bahorun, \& Crozier, 2003). Therefore, the consumption of one fruit of $15 \mathrm{~g}$ will provide more than four times the recommended daily intake of vitamin $\mathrm{C}$ for adults.

\subsubsection{Volatile compounds}

Volatile compounds are a diverse group of organic compounds, generally with a low molecular weight $(<250 \mathrm{Da})$ and high vapor pressure under ambient conditions, allowing them to readily diffuse through the gas phase and within biological systems. In fruits, volatile compounds are responsible for aroma characteristics, including various chemical substances (Chitarra and Chitarra, 2005).

The volatile composition of araçá has been reported by different authors using different techniques such as simultaneous steam distillation and extraction (Pino, Marbot, \& Vázquez, 2001), hydrodistillation (Biegelmeyer et al., 2011; Marin et al., 2008) and dynamic headspace extraction (Egea, Pereira-Netto, Cacho, Ferreira, \& Lopez, 2014).

(E)- $\beta$-caryophyllene was the major constituent in both yellow and red araçá, in all studies. Nevertheless, due to the variability of the sample (e.g. different locations and edaphoclimatic conditions), and the extraction method employed, the profile of yellow and red araçá is quite different. Apart from (E)- $\beta$-caryophyllene, hexadecanoic acid, $(Z)$ 3-hexenol and $\alpha$-pinene were the major constituents found in red araçá studied by (Pino et al., 2001), while $\beta$-selinene and neointermedeol were those from the study of (Biegelmeyer et al., 2011). Concerning the yellow araçá, neointermedeol (Marin et al., 2008), $\alpha$-humulene (Biegelmeyer et al., 2011; Marin et al., 2008), $\beta$-selinene (Marin et al., 2008) and geraniol (Biegelmeyer et al., 2011) were the major compounds.

Although, previous work (Pino et al., 2001) did not found one or more compounds that impact the red araçá odor, they linked the araçá flavor with the presence of aliphatic esters and terpenic compounds. Yellow and red araçá fruit share a common citric, green and sweet flavor pattern, however, they were distinct according to tropical fruit characteristic, found for the YG, and tomato characteristic for the RG (Egea et al., 2014). The compound with highest impact on both yellow and red araçá odor characteristics were: $(Z)$-3-hexenal (grass, herbaceous), that was the main active odorant in tomato; 1,8-cineole (minty and eucalyptus) and (Z)-1,5-Octadien-3-one (geranium). The tropical odor associated with the yellow araça was supposed to be for the presence of 3-mercaptohexyl acetate with fresh and citrus aroma descriptors. Nevertheless, other compounds were also present and together can explain the distinction between the two genotypes. In fact authors attribute the odor of araçá as a result of interaction of compounds present in the fruit (Egea et al., 2014).

The investigation about the pharmacological activities of volatile compounds has increased in the last years since different studies shows their potential application on human health as antioxidant, hepatoprotective, anti-inflammatory, anticarcinogenic and anti-obesity, among other (Ayseli and Ayseli, 2016; Vinholes, Gonçalves, et al., 2014; Vinholes, Rudnitskaya, et al., 2014). (E)-ß-Caryophyllene for 
Table 2

Carotenoids from Psidium cattleianum yellow genotype.

\begin{tabular}{|c|c|c|c|c|}
\hline \multirow[t]{3}{*}{ Compounds } & \multicolumn{3}{|c|}{ Concentration } & \multirow[t]{3}{*}{ Reference } \\
\hline & \multicolumn{3}{|c|}{ Yellow genotype } & \\
\hline & skin & pulp & whole fruit & \\
\hline all-trans-Antheraxanthin & $9.0^{\mathrm{a}}$ & $1.6^{\mathrm{a}}$ & & Ribeiro et al. (2014) \\
\hline \multirow{3}{*}{ all-trans-Lutein } & $10.0^{\mathrm{a}}$ & $1.9^{\mathrm{a}}$ & & Ribeiro et al. (2014) \\
\hline & & $15.7^{\mathrm{b}}$ & & Silva et al. (2014) \\
\hline & & & $26.4^{c}$ & Pereira et al. (2012) \\
\hline 5,6-Epoxy- $\beta$-cryptoxanthin & $7.0^{\mathrm{a}}$ & $2.4^{\mathrm{a}}$ & & Ribeiro et al. (2014) \\
\hline 5,8 -Epoxy- $\beta$-cryptoxanthin & & $3.5^{\mathrm{b}}$ & & Silva et al. (2014) \\
\hline \multirow[t]{2}{*}{ all-trans- $\beta$-Cryptoxanthin } & $6.0^{\mathrm{a}}$ & $3.4^{\mathrm{a}}$ & & Ribeiro et al. (2014) \\
\hline & & 26.4 & & Silva et al. (2014) \\
\hline all-trans- $\alpha$-Cryptoxanthin & & $3.6^{\mathrm{b}}$ & & Silva et al. (2014) \\
\hline Apocarotenoid & & $1.9^{\mathrm{b}}$ & & Silva et al. (2014) \\
\hline \multirow[t]{2}{*}{ all-trans- $\beta$-Carotene } & $5.9^{\mathrm{a}}$ & $3.7^{\mathrm{a}}$ & & Ribeiro et al. (2014) \\
\hline & & $20.0^{\mathrm{b}}$ & & Silva et al. (2014) \\
\hline \multirow[t]{2}{*}{ 9-cis- $\beta$-Carotene } & & $3.0^{\mathrm{b}}$ & $1.3^{\mathrm{c}}$ & Pereira et al. (2012) \\
\hline & & & & Silva et al. (2014) \\
\hline 13-cis- $\beta$-Carotene & & & $1.2^{\mathrm{c}}$ & Pereira et al. (2012) \\
\hline 5,6-epoxy- $\beta$-Carotene & & & $1.2^{\mathrm{c}}$ & Pereira et al. (2012) \\
\hline$\alpha$-Carotene & & & $4.0^{c}$ & Pereira et al. (2012) \\
\hline$\beta$-Carotene & & & $2.9^{c}$ & Pereira et al. (2012) \\
\hline all-trans-Zeaxanthin & & & $137.5^{\mathrm{c}}$ & Pereira et al. (2012) \\
\hline $13^{\prime}$-cis- $\beta$-Cryptoxanthin phytoene & & $0.6^{\mathrm{b}}$ & & Silva et al. (2014) \\
\hline Cryptoxanthin & & & $0.9^{c}$ & Pereira et al. (2012) \\
\hline
\end{tabular}

${ }^{\text {a }}$ Expressed as $\mu \mathrm{g} / \mathrm{g}$ of extract.

${ }^{\mathrm{b}}$ Expressed as $\mu \mathrm{g} / 100 \mathrm{~g}$ fresh weight.

c Expressed as g/g dry matter.

instance, the major volatile compound in araçá, has antioxidant (Calleja et al., 2013; Elmann et al., 2009; Rather et al., 2012), anticarcinogenic, analgesic (Fidyt, Fiedorowicz, Strządała, \& Szumny, 2016), hepatoprotective (Calleja et al., 2013) and neuroprotective (Chang, Kim, \& Chun, 2007) properties. Moreover, this compound attenuates hyperglycemia and mediated oxidative and inflammatory stress in diabetic rat (Basha and Sankaranarayanan, 2016) and protects plasma and tissue glycoprotein components in streptozotocin-induced hyperglycemic rat (Basha and Sankaranarayanan, 2015).

\subsubsection{Carotenoids}

Carotenoids are a diverse group of natural pigments which have received considerable attention since they are potential protector agents against disturbances caused by reactive oxygen species (Fiedor and Burda, 2014).

Levels of total carotenoids in araçá vary considerably, with values of $389.0-1084.0 \mu \mathrm{g}$ and 364.4-1134.0 $\mu \mathrm{g}$ of equivalents of $\beta$-carotene/ $100 \mathrm{~g}$ fresh weight (fw), for yellow and red araçá, respectively (Denardin et al., 2014; Medina et al., 2011; Vinholes, Lemos, Barbieri, Franzon, \& Vizzotto, 2017).

Tables 2 and 3 presents the individual carotenoids reported in yellow and red araçá genotypes, respectively. Major individual carotenoids compounds in fresh yellow araçá were all-trans- $\beta$-cryptoxanthin

Table 3

Carotenoids from Psidium cattleianum red genotype.

\begin{tabular}{|c|c|c|}
\hline \multirow[t]{2}{*}{ Compounds } & Concentration $^{\mathrm{a}}$ & \multirow[t]{2}{*}{ Reference } \\
\hline & $\begin{array}{l}\text { Red genotype } \\
\text { skin }+ \text { pulp }\end{array}$ & \\
\hline all-trans-lutein & 557.8 & \multirow[t]{5}{*}{ Dalla Nora, Jablonski, et al. (2014) } \\
\hline all-trans- $\beta$-cryptoxanthin & 1029.8 & \\
\hline$\alpha$-carotene & 60.8 & \\
\hline$\beta$-carotene & 512.6 & \\
\hline zeaxanthin & 137.5 & \\
\hline
\end{tabular}

\footnotetext{
${ }^{\text {a }}$ Expressed as $\mu \mathrm{g} / \mathrm{g}$ of extract.
}

$(26.4 \mu \mathrm{g} \pm 1.9 \mu \mathrm{g} / 100 \mathrm{~g} \mathrm{fw}), \quad$ all-trans- $\beta$-carotene $\quad(20.0 \mu \mathrm{g} \pm 4.6 \mu \mathrm{g} /$ $100 \mathrm{~g} \mathrm{fw})$ and all-trans-lutein $(15.7 \mu \mathrm{g} \pm 3.8 \mu \mathrm{g} / 100 \mathrm{~g} \mathrm{fw}) \quad$ (Silva, Rodrigues, Mercadante, \& Rosso, 2014). Although other authors found similar composition, major compounds in skin and pulp were different being all-trans-lutein, all-trans-antheraxanthin, all-trans- $\beta$-carotene and alltrans- $\beta$-cryptoxanthin the most representative compounds in araça studied by (Ribeiro et al., 2014). Lutein was also the main carotenoid compound in yellow araçá studied by (Pereira et al., 2012), followed by $\alpha$-carotene, zeaxanthin and $\beta$-carotene. The composition of red araçá genotype is quite similar to the yellow one, as reported by Silva et al., 2014, with all-trans- $\beta$ cryptoxanthin as a major compound, however all-trans-lutein was in the second position, and all-trans- $\beta$-carotene in the third, but with very close values (Dalla Nora, Jablonski, et al., 2014).

Carotenoids are important antioxidant compounds which ingestion can significantly reduce the risk of diseases associated with oxidative stress. The beneficial effects of carotenoids have been confirmed in different types of cancer, cardiovascular and eyes disorders (Fiedor and Burda, 2014). Improvements in baseline blood pressure, reduction of inflammation and correction of dyslipidemias can also be highlighted (Maria, Graziano, \& Nicolantonio, 2015).

\subsubsection{Phenolic compounds}

The total content of phenolic compounds and flavonoids, expressed in fresh weight, were reported to be more abundant in red araçá ( $501.33 \mathrm{mg}$ of gallic acid equivalents (GAE)/100 $\mathrm{g}$ and $200.20 \mathrm{mg}$ of quercetin equivalents $(\mathrm{QE}) / 100 \mathrm{~g}$, respectively) than in yellow one (292.03 $\mathrm{mg}$ of $\mathrm{GAE} / 100 \mathrm{~g}$ and $35.12 \mathrm{mg}$ of $\mathrm{QE} / 100 \mathrm{~g}$, respectively) (Table 4) (Biegelmeyer et al., 2011). However, in other studies, the total content of phenolic compounds did not differ between yellow and red genotypes, for instance, $5372 \mathrm{mg}$ and $5638 \mathrm{mg}$ of GAE acid/100 g and $603 \mathrm{mg}$ and $606 \mathrm{mg}$ of chlorogenic acid equivalent (CAE)/100 g, were reported for YG and RG, respectively (Table 4) (Luximon-Ramma et al., 2003; Vinholes et al., 2017).

Differences were observed for proanthocyanidins contents (2561 mg and $2473 \mathrm{mg}$ of cyanidin chloride (CE)/g in the red and in the yellow araçá, respectively) and flavonoids contents $(712 \mathrm{mg}$ of $\mathrm{QE} / \mathrm{g}$ in the red 


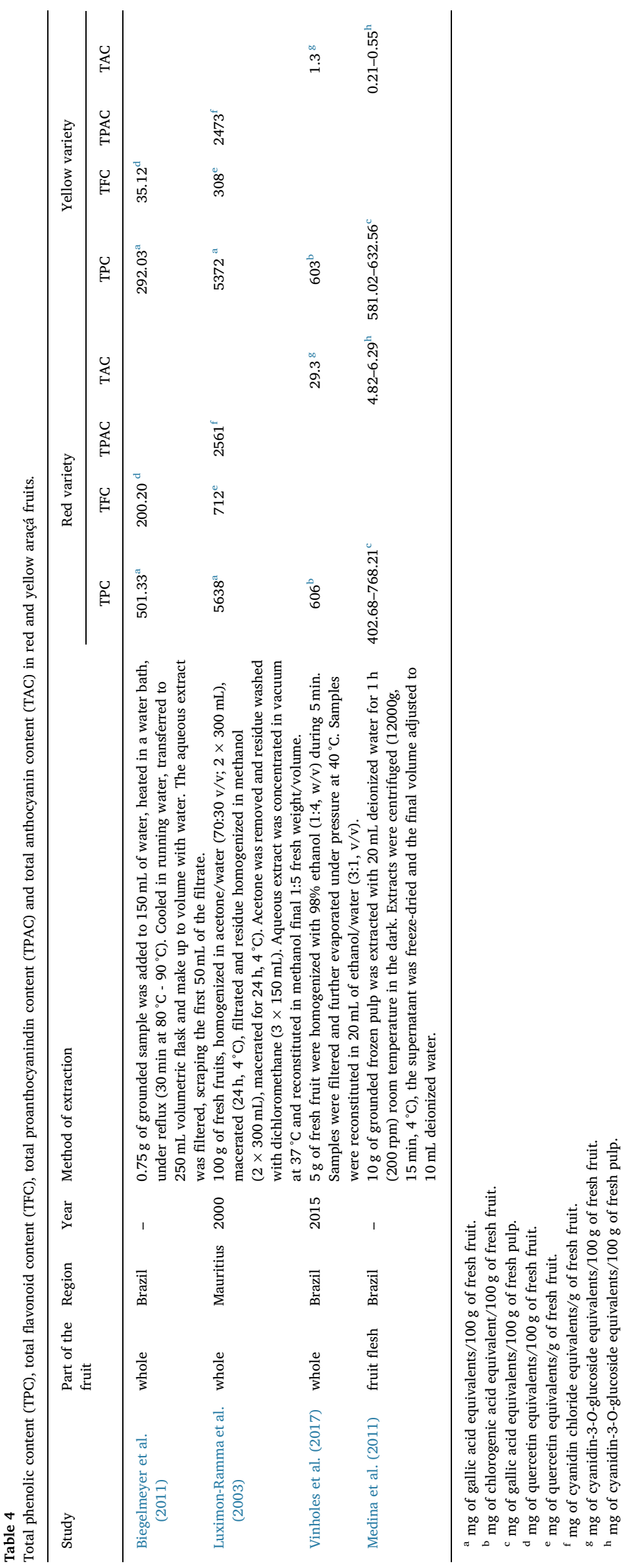


araçá against $308 \mathrm{mg}$ of QE/g in the yellow araçá) (Luximon-Ramma et al., 2003). The higher amount of flavonoids in the red variety can be explained by the presence of cyanidins.

The total content of phenolic compounds varies considerably between different accessions. Three different accessions of red araçá showed total content of phenolic compound varying from $402.68 \mathrm{mg}$ to $528.30 \mathrm{mg}$ of GAE/100 $\mathrm{g}$ fresh fruit pulp (ffp), while yellow accessions (3) varied from $581.02 \mathrm{mg}$ to $632.56 \mathrm{mg}$ of GAE/100 $\mathrm{g} \mathrm{ffp}$ (Medina et al., 2011) (Table 4). Anthocyanins were present in much higher amounts in the red accessions (4.82-6.29 mg cyanidin-3-O-glucoside (C-3-O-G)/100 $\mathrm{g} \mathrm{ffp})$ than in the yellow ones $(0.21-0.55 \mathrm{mg} \mathrm{C}-3-\mathrm{O}-\mathrm{G} /$ $100 \mathrm{~g}$ ffp) (Table 4). A similar result was observed by other author (Vinholes et al., 2017) (Table 4).

These quantitative differences observed for total phenolic content in araça can be due to the cultivation region, edaphoclimatic conditions and agricultural year of the studies (Table 4). In addition, the part of the fruit utilized and the method of extraction can also be responsible for the observed differences. Most of the studies used the whole fruit, with the exception of Medina et al. (2011) who evaluated the composition of the pulp. In respect of the method of extraction, Luximon-Ramma et al. (2003) used a multi-step extraction procedure including long periods of maceration with solvents with different polarities and removal of fat soluble substances prior phenolic contents analysis, while other authors used more simple methods (Table 4).

Araçá studied by different groups of researchers showed a different individual phenolic profile (Tables 5 and 6).

The most representative phenolic compounds in yellow genotypes were: gallic acid and its derivatives and ellagic acid and its derivatives Higher concentrations of phenolic compounds were found in the yellow araça pulp when compared with the concentration found in the yellow araçá skin (Ribeiro et al., 2014) (Table 5). Phenolic composition of red araçá genotypes accounts with 9 compounds, being epicatechin and gallic acid the majors ones (Table 6). Although red and yellow araçá genotypes have some common phenolic compounds as described by Medina et al. (2011), there is a lack of studies comparing the full individual phenolic profile of both araçá genotypes.

Phenolic compounds are secondary metabolites of plants and are essential for their growth and reproduction. Besides, they are formed in stress conditions, such as infections, wounds, UV radiations among others (Naczk and Shahidi, 2004).

There is growing evidence that consumption of phenolic compounds present in foods may lower the risk of health disorders due to their antioxidant activity (Shahidi and Ambigaipalan, 2015). Phenolic compounds acts over reactive oxygen species and free radicals, which are in the origin of pathophysiology of neoplasia, atherosclerosis and neurodegenerative diseases (Heim, Tagliaferro, \& Bobilya, 2002). In fact, major phenolic compounds present in araçás (gallic acid, ellagic acid, epicatechin and quercetin), are described with chelating properties, inhibition of lipid peroxidation, responsible for the maintenance of endogenous antioxidant defense system, anti-inflammatory, antiproliferative and antimicrobial effects among others (Badhani, Sharma, \& Kakkar, 2015; Chanwitheesuk, Teerawutgulrag, Kilburn, \& Rakariyatham, 2007; García-Niño and Zazueta, 2015; Jagan, Ramakrishnan, Anandakumar, Kamaraj, \& Devaki, 2008; Kaur, Velmurugan, Rajamanickam, Agarwal, \& Agarwal, 2009; Long et al., 2016; Shay et al., 2015; Tadera, Minami, Takamatsu, \& Matsuoka, 2006; Wang et al., 2016). Moreover, (-)-epicatechin and quercetin are considered good inhibitors of alfa-glucosidase and alfa-amylase, key enzymes in the control of type II diabetes mellitus (Tadera et al., 2006). Procyanidins, found in both araçás genotypes, also have antidiabetic properties. It was found that they possess insulin mimetic functions, reducing the hyperglycemia and stimulating the glucose absorption in cell lines sensitive to insulin (Montagut et al., 2010).

\section{Biological activities}

\subsection{Antioxidant activity}

In vitro studies. $P$. cattleianum can be considered as a good source of bioactive compounds with antioxidant properties (McCook-Russell, Nair, Facey, \& Bowen-Forbes, 2012; Dalla Nora, Jablonski, et al., 2014). According to (Ribeiro et al., 2014), araçá is a potent scavenger of reactive oxygen and nitrogen species, besides its pulp has also the potential of $\mathrm{O}_{2}{ }^{-}$, $\mathrm{HOCl}$ and ${ }^{1} \mathrm{O}_{2}$ scavenger. Similar results were obtained by (Vinholes et al., 2017) were edible portions of araçá from yellow and red genotypes showed good inhibition properties against $\mathrm{O}_{2}{ }^{-}$and hydroxyl radicals.

Fetter, Vizzotto, Corbelini, and Gonzales (2010) and Medina et al. (2011) reported that araçá extracts with higher content of phenolic compounds where those with higher antioxidant activity. Moreover, red genotypes were more effective against DPPH than the yellow genotypes, which authors suggest to be probably by their higher anthocyanins content. Nevertheless, results obtained in other study shows that yellow araçá ( $\mathrm{IC}_{50}=334.3 \mu \mathrm{g} / \mathrm{mL} \pm 16.5 \mu \mathrm{g} / \mathrm{mL}$ ) were more effective against DPPH than the red genotype $\left(\mathrm{IC}_{50}=490.3 \mu \mathrm{g} / \mathrm{mL} \pm 35.1 \mu \mathrm{g} /\right.$ mL) (Vinholes et al., 2017).

Araçá also showed good antioxidant protection of yeast (Saccharomyces cerevisiae) against hydrogen peroxide at a concentration of $25 \%$. In fact, the action was independent of genotype and extraction solvent used, and yeast survival rates were above $80 \%$ (Medina et al., 2011). Hydrogen peroxide is formed during the normal cell metabolism and can cause damage to protein, lipid and DNA, mainly by the generation of hydroxyl radicals through the Haber-Weiss/Fenton (Caillet et al., 2007).

In vivo studies. Rats fed with powdered freeze-dried araçá showed remarkable decrease on parameters altered by oxidative stress induced by cisplatin. Animals showed lowered levels of glucose, LDL cholesterol, oxidized LDL cholesterol and total cholesterol when compared with control animals (cisplatin-induced animals not feed with araçá). Also, animals fed with araçá decreased fat deposition in the liver showing an improvement in the lipid profile (Dalla Nora, Danelli, et al., 2014). More recently, the administration of araçá extract $(200 \mathrm{mg} / \mathrm{kg}$ / day, for 21 days) to insulin resistant rats prevented the liver lipid peroxidation and the formation of reactive oxygen species (de Souza Cardoso et al., 2017).

\subsection{Antidiabetic activity}

In vitro studies. Araçá extracts were evaluated as potential inhibitor of digestive enzymes and it was verified that red araçá genotypes were able to inhibit alfa-glucosidase e alfa-amylase enzymes, being an alternative to the modulation of hyperglycemia (Pacheco, 2015). Nevertheless, araçá extracts of both genotypes were described as very effective against alfa-glucosidase enzyme with inhibitory concentrations of $50 \%$ of the enzyme, 13 times and 16 times lower than the positive control (acarbose) (Vinholes et al., 2017).

In vivo studies. Administration of $P$. cattleianum extract $(200 \mathrm{mg} / \mathrm{kg} /$ day, for 21 days) prevented hyperglycemia and hypertriglyceridemia in insulin resistant rats induced by dexamethasone (de Souza Cardoso et al., 2017). The mechanism of action of the extract was not reported by authors. Nevertheless, this activity can be related with some of the phenolic compounds present in araçá extracts, since these compounds are responsible for inhibiting specific enzymes (Valko et al., 2007). Quercetin, for instance, is considered a good inhibitor of digestive enzymes with $\mathrm{IC}_{50}$ almost 40 times lower than the positive control (Vinholes et al., 2017).

\subsection{Anticancer activity}

Araçá extracts from red and yellow genotypes were tested (in vitro) 
Table 5

Individual phenolic compounds found in yellow araçá fruits.

\begin{tabular}{|c|c|c|c|}
\hline \multirow[t]{2}{*}{ Compounds } & \multicolumn{2}{|c|}{ Yellow } & \multirow[t]{2}{*}{ References } \\
\hline & skin & pulp & \\
\hline Epicatechin & & $720.5-2659.5^{\mathrm{a}}$ & Medina et al. (2011) \\
\hline Epicatechin epicatechin & & $5.4^{\mathrm{b}}$ & Silva et al. (2014) \\
\hline Epicatechin gallate & $885.0^{c}$ & $1603.0^{c}$ & Ribeiro et al. (2014) \\
\hline Coumaric acid & & $2.6-36.0^{\mathrm{a}}$ & Medina et al. (2011) \\
\hline Ferulic acid & & $2.0-4.4^{\mathrm{a}}$ & Medina et al. (2011) \\
\hline Myricetin & & $0.1-3.8^{\mathrm{a}}$ & Medina et al. (2011) \\
\hline Chlorogenic acid & $60.0^{c}$ & $121.0^{c}$ & Ribeiro et al. (2014) \\
\hline Chlorogenic acid hexoside & $29.0^{c}$ & $26.0^{c}$ & Ribeiro et al. (2014) \\
\hline \multirow[t]{3}{*}{ Gallic acid } & $464.0^{c}$ & $297.7-726.7^{\mathrm{a}}$ & Medina et al. (2011) \\
\hline & & $1510.0^{\mathrm{c}}$ & Ribeiro et al. (2014) \\
\hline & & $12.2^{\mathrm{b}}$ & Silva et al. (2014) \\
\hline Galloyl hexoside & & $7.4^{\mathrm{b}}$ & Silva et al. (2014) \\
\hline Digalloyl hexoside & & $2.9^{\mathrm{b}}$ & Silva et al. (2014) \\
\hline Trigalloylquinic acid & $9.0^{\mathrm{c}}$ & $85.0^{c}$ & Ribeiro et al. (2014) \\
\hline Ellagic acid & $2213.0^{c}$ & $3818.0^{c}$ & Ribeiro et al. (2014) \\
\hline Ellagic acid hexoside & $136.0^{c}$ & $346.0^{c}$ & Ribeiro et al. (2014) \\
\hline Ellagic acid pentoside & $164.0^{\mathrm{c}}$ & $412.0^{c}$ & Ribeiro et al. (2014) \\
\hline Ellagic acid deoxyhexoside & $1475.0^{c}$ & $2070.0^{c}$ & Ribeiro et al. (2014) \\
\hline Ellagitanin-like & $77.0^{c}$ & $1022.0^{c}$ & Ribeiro et al. (2014) \\
\hline HHDP hexoside & & $5.7^{\mathrm{b}}$ & Silva et al. (2014) \\
\hline \multirow[t]{2}{*}{ Di-HHDP-hexoside } & $222.0^{\mathrm{c}}$ & $150.0^{c}$ & Ribeiro et al. (2014) \\
\hline & & $4.0^{\mathrm{b}}$ & Silva et al. (2014) \\
\hline Di-HHDP-hexoside isomer & & $3.9^{\mathrm{b}}$ & Silva et al. (2014) \\
\hline HHDP digalloyl hexoside & & $2.3^{\mathrm{b}}$ & Silva et al. (2014) \\
\hline HHDP digalloyl hexoside isomer & & $5.9^{\mathrm{b}}$ & Silva et al. (2014) \\
\hline \multirow[t]{2}{*}{ Quercetin } & $115.0^{c}$ & $2.0-6.8^{\mathrm{a}}$ & Medina et al. (2011) \\
\hline & & $32.0^{\mathrm{c}}$ & Ribeiro et al. (2014) \\
\hline Quercetin glucuronide & $20.0^{c}$ & $18.0^{\mathrm{c}}$ & Ribeiro et al. (2014) \\
\hline \multirow[t]{2}{*}{ Quercetin hexoside } & $17.5^{\mathrm{c}}$ & $11.4^{\mathrm{c}}$ & Ribeiro et al. (2014) \\
\hline & & $6.4^{\mathrm{b}}$ & Silva et al. (2014) \\
\hline Quercetin pentoside & $39.0^{c}$ & $27.0^{\mathrm{c}}$ & Ribeiro et al. (2014) \\
\hline Quercetin deoxyhexoside & $53.0^{c}$ & $11.2^{\mathrm{c}}$ & Ribeiro et al. (2014) \\
\hline Quercetin coumaroyl deoxyhexoside & $15.0^{\mathrm{c}}$ & $8.5^{c}$ & Ribeiro et al. (2014) \\
\hline Methyl ellagic acid hexoside & & $5.2^{\mathrm{b}}$ & Silva et al. (2014) \\
\hline Methyl ellagic acid pentoside & & $5.6^{\mathrm{b}}$ & Silva et al. (2014) \\
\hline Methyl ellagic acid deoxyhexoside & $475.0^{c}$ & $646.0^{c}$ & Ribeiro et al. (2014) \\
\hline Methyl ellagic acid deoxyhexoside & $34.0^{\mathrm{c}}$ & $20.0^{\mathrm{c}}$ & Ribeiro et al. (2014) \\
\hline Methyl ellagic acid acetyl-deoxyhexoside & $10.0^{c}$ & $2.0^{c}$ & Ribeiro et al. (2014) \\
\hline Cinnamoyl-galloyl hexoside & $573.0^{c}$ & $880.0^{c}$ & Ribeiro et al. (2014) \\
\hline Vanillic acid hexoside & & $8.1^{\mathrm{b}}$ & Silva et al. (2014) \\
\hline Taxifolin hexoside & & $11.7^{\mathrm{b}}$ & Silva et al. (2014) \\
\hline Eriodictyol hexoside & & $4.0^{\mathrm{b}}$ & Silva et al. (2014) \\
\hline
\end{tabular}

${ }^{\mathrm{a}}$ Results expressed as $\mu \mathrm{g} / \mathrm{g}$ of fresh pulp.

${ }^{\mathrm{b}}$ Results expressed as $\mathrm{mg} / 100 \mathrm{~g}$ of fresh pulp.

${ }^{c}$ Expressed as $\mu \mathrm{g} / \mathrm{g}$ extract.

Table 6

Individual phenolic compounds found in red araçá fruits.

\begin{tabular}{lll}
\hline Compounds & Red pulp & References \\
\hline Epicatechin & $263.9-2130.4^{\mathrm{a}}$ & Medina et al. (2011) \\
Coumaric acid & $3.3-31.7^{\mathrm{a}}$ & Medina et al. (2011) \\
Ferulic acid & $3.3-8.1^{\mathrm{a}}$ & Medina et al. (2011) \\
Myricetin & $0.2-14.0^{\mathrm{a}}$ & Medina et al. (2011) \\
Cyanidin-3-O-glicoside & $354.7^{\mathrm{b}}$ & Dalla Nora, Jablonski, et al. (2014) \\
Malvidin-3-O-glicoside & $243.6^{\mathrm{b}}$ & Dalla Nora, Jablonski, et al. (2014) \\
Cyanidin & $87.6^{\mathrm{b}}$ & Dalla Nora, Jablonski, et al. (2014) \\
Gallic acid & $193.2-801.0^{\mathrm{a}}$ & Medina et al. (2011) \\
Quercetin & $0.2-6.6^{\mathrm{a}}$ & Medina et al. (2011)
\end{tabular}

${ }^{a}$ Results expressed as $\mu \mathrm{g} / \mathrm{g}$ of fresh pulp.

${ }^{\mathrm{b}}$ Expressed as $\mu \mathrm{g} / \mathrm{g}$ dry fruit.

as antiproliferative agents on mammary cancer cells (MCF-7) and colon cancer cells (Caco-2 cells) using rat embryonic fibroblast cells 3T3 as control (Medina et al., 2011). Water and acetone extracts were tested at concentrations of 40,60 and $80 \mu \mathrm{g} / \mathrm{mL}$ and it was observed a reduction on proliferation of both cancerous cells. Results were dependent of the concentration and independent of genotype. In addition, control cells survival was not affected by the extracts at the highest concentration tested. This result suggests that the araçá antiproliferative effect observed for cancerous cells was other than toxicity.

\subsection{Antimicrobial activity}

Araçá fruit extract showed in vitro antibacterial activity against Salmonella enteritidis, an enteric, food-borne pathogen, frequently described in the literature on the occurrence of toxinfections in humans. Extracts showed minimum inhibitory concentration at 5\% and it was verified that extracts with higher secondary metabolites concentrations were more effective against the bacterial proliferation (Medina et al., 2011). Intermediate activity was reported for araçá against Bacillus subtilis and Staphylococcus aureus (McCook-Russell et al., 2012). The antimicrobial activity of plants is mainly related with the presence of phenolic compounds in leaves and fruits. Araçá contains flavonoids (i.e. kaempferol and quercetin) and anthocyanidins (cyanidin) that are well recognized antimicrobial agents. These compounds mode of action is related with their reaction with microbial cellular membrane inactivating essential enzymes, or forming complexes with metallic ions, limiting their accessibility to the microbial metabolism (Medina et al., 2011). 


\subsection{Anti-inflammatory activity}

The in vitro anti-inflammatory activity of araçá was tested using hexane and ethyl acetate extracts. Reported activity at $250 \mu \mathrm{g} / \mathrm{mL}$ were $18.3 \%$ and $26.5 \%$ inhibition of ciclooxigenase- 2 enzyme by hexane and ethyl acetate extracts, respectively (McCook-Russell et al., 2012). Authors also tested isolated compounds, the mixture of ursolic and oleanolic acids, for instance, showed $19.4 \%$ of inhibition at the same concentration tested for the araçá extracts. In addition, the mixture of isolated compounds 2- $\alpha$-hydroxyursolic and 2- $\alpha$-hydroxyoleanolic acids showed inhibition of $52.9 \%$ and $43.1 \%$ for COX-2 and COX-1, respectively (McCook-Russell et al., 2012).

\subsection{Anti-aging activity}

A long term in vivo experiment (8 months) carried out on adult mices fed with araçá extract $(1000 \mathrm{mg} / \mathrm{kg} /$ day $)$ showed that hippocampus gene expression profile were different from control animals. Authors found that araçá altered the expression of genes associated with regulation of essential cellular processes such as cell cycle, proliferation, differentiation and signal transduction, regulate inflammatory genes (inhibiting inflammatory process) and up-regulate genes encoding for proteins involved in radical scavenging (Ramirez, Zanchin, Henriques, \& Zuanazzi, 2012).

\section{Conclusions}

This review aimed to explore the chemical composition and biological potential of araçás in order to valorize this native fruit. The succulence and sweet taste of araçá pulp has been of interest to the food industry. In addition, there was an increased interest in the pharmaceutical area due to the findings on the nutritional properties of this fruit. Different studies indicate promising pharmacological properties mainly related to its chemical properties. The phenolic compounds present in araçás, such as gallic acid, ellagic acid, epicatechin and quercetin are described by the maintenance of the endogenous antioxidant defense system, anti-inflammatory, antiproliferative and antimicrobial. Thus, araçás can be useful in the prevention and treatment of pathologies associated to oxidative stress and aging. Moreover, it seems to be a potential candidate to be used in the management of type 2 Diabetes mellitus.

\section{Acknowledgments}

This work was supported by Institute of International Education (CAPES), Brazil [process number 1591849, grant number 2016/2018], and National Council for Scientific and Technological Development (CNPq), Brazil, [process number 400201/2014-3, grant number 313712/2014-0].

\section{References}

Adrian, J. A. L., Arancon, N. Q., Mathews, B. W., \& Carpenter, J. R. (2015). Mineral composition and soil-plant relationships for common Guava (Psidium guajava L.) and yellow strawberry Guava (Psidium cattleianum var. lucidum) tree parts and fruits. Communications in Soil Science and Plant Analysis, 46, 1960-1979. http://dx.doi.org/ 10.1080/00103624.2015.1069310.

Ayseli, M. T., \& Ayseli, Y. I. (2016). Flavors of the future: Health benefits of flavor precursors and volatile compounds in plant foods. Trends in Food Science and Technology, 48, 69-77. http://dx.doi.org/10.1016/j.tifs.2015.11.005.

Badhani, B., Sharma, N., \& Kakkar, R. (2015). Gallic acid: A versatile antioxidant with promising therapeutic and industrial applications. RSC Advances, 5, 27540-27557. http://dx.doi.org/10.1039/C5RA01911G.

Bailey, R. L., West, K. P., \& Black, R. E. (2015). The epidemiology of global micronutrient deficiencies. Annals of Nutrition and Metabolism, 66, 22-33. http://dx.doi.org/10. $1159 / 000371618$.

Basha, R. H., \& Sankaranarayanan, C. (2016). $\beta$-Caryophyllene, a natural sesquiterpene lactone attenuates hyperglycemia mediated oxidative and inflammatory stress in experimental diabetic rats. Chemico-Biological Interactions, 245, 50-58. http://dx.doi. org/10.1016/j.cbi.2015.12.019.
Basha, R. H., \& Sankaranarayanan, C. (2015). Protective role of $\beta$-caryophyllene, a sesquiterpene lactone on plasma and tissue glycoprotein components in streptozotocininduced hyperglycemic rats. Journal of Acute Medicine, 5, 9-14. http://dx.doi.org/10. 1016/j.jacme.2015.02.001.

Bernaud, F. S. R., \& Rodrigues, T. C. (2013). Fibra alimentar - Ingestão adequada e efeitos sobre a saúde do metabolismo. Arquivos Brasileiros de Endocrinologia \& Metabologia, 57, 397-405. http://dx.doi.org/10.1590/S0004-27302013000600001.

Bezerra, J. E. F., Lederman, I. E., Silva Junior, J. F., \& Proença, C. E. B. (2010). Araça. In R. F. Vieira, T. S. A. Costa, D. B. Silva, F. R. Ferreira, \& S. Sano (Eds.). Frutas Nativas Da Região Centro-Oeste Do Brasil (pp. 42-62). Brasilia, Brazil: Embrapa Informação Tecnológica.

Biegelmeyer, R., Maria, J., Andrade, M., Ana, L., Apel, M. A., Dresch, R. R., \& Marin, R. (2011). Comparative analysis of the chemical composition and antioxidant activity of red (Psidium cattleianum) and yellow (Psidium cattleianum var. lucidum) strawberry Guava fruit. Journal of Food Science, 76, C991-C996. http://dx.doi.org/10.1111/j. 1750-3841.2011.02319.x.

Caillet, S., Yu, H., Lessard, S., Lamoureux, G., Ajdukovic, D., \& Lacroix, M. (2007). Fenton reaction applied for screening natural antioxidants. Food Chemistry, 100, 542-552.

Calleja, M. A., Vieites, J. M., Montero-Meterdez, T., Torres, M. I., Faus, M. J., Gil, A., \& Suárez, A. (2013). The antioxidant effect of $\beta$-caryophyllene protects rat liver from carbon tetrachloride-induced fibrosis by inhibiting hepatic stellate cell activation. British Journal of Nutrition, 109, 394-401. http://dx.doi.org/10.1017/ S0007114512001298.

Castro, C., Raseira, M.do C. B., \& Franzon, R. C. (2004). Descriç̃o da Planta. In M.do C. B. Raseira, L. E. C. Antunes, R. Trevisan, \& E. D. Gonçalves (Eds.). Espécies Frutíferas Nativas Do Sul Do Brasil (pp. 13-28). Pelotas: Embrapa Clima Temperado.

Chang, H.-J., Kim, H. J., \& Chun, H. S. (2007). Quantitative structure-activity relationship (QSAR) for neuroprotective activity of terpenoids. Life Sciences, 80, 835-841. http://dx.doi.org/10.1016/j.lfs.2006.11.009.

Chanwitheesuk, A., Teerawutgulrag, A., Kilburn, J. D., \& Rakariyatham, N. (2007). Antimicrobial gallic acid from Caesalpinia mimosoides Lamk. Food Chemistry, 100, 1044-1048. http://dx.doi.org/10.1016/j.foodchem.2005.11.008.

Chitarra, M. I. F., \& Chitarra, A. B. (2005). Pós-colheita de frutas e hortaliças: fisiologia e manuseio (2nd ed.). Lavras, Minas Gerais, Brazil: Universidade Federal de Lavras.

Dalla Nora, C., Danelli, D., Souza, L. F., Rios, A. D. O., Jong, E. V. De, \& Flôres, S. H. (2014). Protective effect of guabiju (Myrcianthes pungens (O. Berg) D. Legrand) and red guava (Psidium cattleyanum Sabine) against cisplatin-induced hypercholesterolemia in rats. Brazilian Journal of Pharmaceutical Sciences, 50, 483-491.

Dalla Nora, C., Jablonski, A., de Rios, A. O., Hertz, P. F., de Jong, E. V., \& Flôres, S. H. (2014). The characterisation and profile of the bioactive compounds in red guava (Psidium cattleyanum Sabine) and guabiju (Myrcianthes pungens (O. Berg) D. Legrand). International Journal of Food Science \& Technology, 49, 1842-1849. http://dx.doi.org/ 10.1111/ijfs.12493.

de Souza Cardoso, J., Oliveira, P. S., Bona, N. P., Vasconcellos, F. A., Baldissarelli, J., Vizzotto, M., ... Stefanello, F. M. (2017). Antioxidant, antihyperglycemic, and antidyslipidemic effects of Brazilian-native fruit extracts in an animal model of insulin resistance. Redox Report: Communications in Free Radical Research, 1-6.

Denardin, C. C., Hirsch, G. E., da Rocha, R. F., Vizzotto, M., Henriques, A. T., Moreira, J. C. F., ... Emanuelli, T. (2014). Antioxidant capacity and bioactive compounds of four Brazilian native fruits. Journal of Food and Drug Analysis, 23, 387-398. http://dx.doi. org/10.1016/j.jfda.2015.01.006.

Egea, M. B., Pereira-Netto, A. B., Cacho, J., Ferreira, V., \& Lopez, R. (2014). Comparative analysis of aroma compounds and sensorial features of strawberry and lemon guavas (Psidium cattleianum Sabine). Food Chemistry, 164, 272-277. http://dx.doi.org/10. 1016/j.foodchem.2014.05.028.

Elmann, A., Mordechay, S., Rindner, M., Larkov, O., Elkabetz, M., \& Ravid, U. (2009) Protective effects of the essential oil of Salvia fruticosa and its constituents on astrocytic susceptibility to hydrogen peroxide-induced cell death. Journal of Agricultural and Food Chemistry, 57, 6636-6641. http://dx.doi.org/10.1021/jf901162f.

Santos, C. A. F., da Castro, J. M. C. E., de Souza, F. F., Vilarinho, A. A., Ferreira, F. R., Padua, J. G., ... Rodrigues, M. A. (2010). Prospecting and morphological characterization of Brazilian Psidium germplasm. Acta Horticulturae, 849, 63-68. http://dx.doi. org/10.17660/ActaHortic. 2010.849.6.

Fetter, M. R., Vizzotto, M., Corbelini, D. D., \& Gonzales, T. N. (2010). Functional properties of yellow guava, red guava (Psidium cattleyanum Sabine) and pear guava (Psidium acutangulum D.C.) grown in Pelotas/RS - Brazil. Brazilian Journal of Food Technology, 3, 92-95. http://dx.doi.org/10.4260/BJFT20101304115.

Fidyt, K., Fiedorowicz, A., Strządała, L., \& Szumny, A. (2016). $\beta$-Caryophyllene and $\beta$ caryophyllene oxide-Natural compounds of anticancer and analgesic properties. Cancer Medicine, 5, 3007-3017. http://dx.doi.org/10.1002/cam4.816.

Fiedor, J., \& Burda, K. (2014). Potential role of carotenoids as antioxidants in human health and disease. Nutrients, 6, 466-488. http://dx.doi.org/10.3390/nu6020466.

Figueroa-Méndez, R., \& Rivas-Arancibia, S. (2015). Vitamin C in health and disease: Its role in the metabolism of cells and redox state in the brain. Frontiers in Physiology, 6, 1-11. http://dx.doi.org/10.3389/fphys.2015.00397.

Franzon, R. C., de Campos, L. Z. O., Proença, C. E. B., \& Sousa-Silva, J. C. (2009). Araçás do Gênero Psidium: principais espécies, ocorrência, descrição e usos - Documentos 266. Embrapa Cerrados.

Galho, A. S., Lopes, N. E. I. F., Bacarin, M. A., de Lima, M. D. G., \& S. (2007). Chemical composition and growth respiration in Psidium cattleyanum Sabine fruits during the development cycle. Revista Brasileira de Fruticultura, 29, 61-66. http://dx.doi.org/10. 1590/s0100-29452007000100014.

García-Niño, W. R., \& Zazueta, C. (2015). Ellagic acid: Pharmacological activities and molecular mechanisms involved in liver protection. Pharmacological Research, 97, 84-103. http://dx.doi.org/10.1016/j.phrs.2015.04.008.

Hall, N. T., Smoot, J. M., Knight, R. J., \& Nagy, S. (1980). Protein and amino acid 
compositions of ten tropical fruits by gas-liquid chromatography. Journal of Agriculture and Food Chemistry, 28, 1217-1221.

Heim, K. E., Tagliaferro, A. R., \& Bobilya, D. J. (2002). Flavonoid antioxidants: Chemistry, metabolism and structure-activity relationships. The Journal of Nutritional Biochemistry, 13, 572-584.

Hur, S. J., Kim, Y. C., Choi, I., \& Lee, S. K. (2013). The effects of biopolymer encapsulation on total lipids and cholesterol in egg yolk during in vitro human digestion. International Journal of Molecular Sciences, 14, 16333-16347. http://dx.doi.org/10 3390/ijms140816333.

Jagan, S., Ramakrishnan, G., Anandakumar, P., Kamaraj, S., \& Devaki, T. (2008). Antiproliferative potential of gallic acid against diethylnitrosamine-induced rat hepatocellular carcinoma. Molecular and Cellular Biochemistry, 319, 51-59. http://dx. doi.org/10.1007/s11010-008-9876-4.

Kaur, M., Velmurugan, B., Rajamanickam, S., Agarwal, R., \& Agarwal, C. (2009). Gallic acid, an active constituent of grape seed extract, exhibits anti-proliferative, proapoptotic and anti-tumorigenic effects against prostate carcinoma xenograft growt in nude mice. Pharmaceutical Research, 26, 2133-2140. http://dx.doi.org/10.1007/ s11095-009-9926-y.

Kinupp, V. F., \& Inchausti, I. B. (2008). Teores de proteína e minerais de espécies nativas, potenciais hortalicas e frutas Protein and mineral contents of native species, potential vegetables, and fruits. Ciência e Tecnologia de Alimentos, 28, 846-857.

Koba, K., \& Yanagita, T. (2014). Health benefits of conjugated linoleic acid (CLA). Obesity Research \& Clinical Practice, 8, e525-e532. http://dx.doi.org/10.1016/j.orcp.2013. 10.001.

Lisbôa, G. N., Kinupp, V. F., \& de Barros, I. B. I. (2011). Psidium cattleianum Araçá. In L. Coradin, A. Siminski, \& A. Reis (Eds.). Espécies Nativas Da Flora Brasileira de Valor Econômico Atual Ou Potencial Plantas Para O Futuro - Região Sul (pp. 205-208). Brasilia, Brazil: Ministério do Meio Ambiente.

Long, M., Yang, S. H., Han, J. X., Li, P., Zhang, Y., Dong, S., ... He, J. Bin (2016). The protective effect of grape-seed proanthocyanidin extract on oxidative damage induced by zearalenone in kunming mice liver. International Journal of Molecular Sciences, 17, 808. http://dx.doi.org/10.3390/ijms17060808.

Luximon-Ramma, A., Bahorun, T., \& Crozier, A. (2003). Antioxidant actions and phenolic and vitamin C contents of common Mauritian exotic fruits. Journal of the Science of Food and Agriculture, 502, 496-502. http://dx.doi.org/10.1002/jsfa.1365.

Maria, A. G., Graziano, R., \& Nicolantonio, D. O. (2015). Carotenoids: Potential allies of cardiovascular health? Food \& Nutrition Research, 59, 26762.

Marin, R., Apel, M. A., Limberger, R. P., Raseira, M. C. B., Pereira, J. F. M., Zuanazzi, J.Â. S., \& Henriques, A. T. (2008). Volatile components and antioxidant activity from some Myrtaceous fruits cultivated in Southern Brazil. Latin American Journal of Pharmacy, 27, 172-177.

McCook-Russell, K. P., Nair, M. G., Facey, P. C., \& Bowen-Forbes, C. S. (2012). Nutritional and nutraceutical comparison of Jamaican Psidium cattleianum (strawberry guava) and Psidium guajava (common guava) fruits. Food Chemistry, 134, 1069-1073. http:// dx.doi.org/10.1016/j.foodchem.2012.03.018.

Medina, A. L., Haas, L. I. R., Chaves, F. C., Salvador, M., Zambiazi, R. C., Da Silva, W. P., ... Rombaldi, C. V. (2011). Araçá (Psidium cattleianum Sabine) fruit extracts with antioxidant and antimicrobial activities and antiproliferative effect on human cancer cells. Food Chemistry, 128, 916-922. http://dx.doi.org/10.1016/j.foodchem.2011.03. 119.

Mitra, S. K., Irenaeus, T. K. S., Gurung, M. R., \& Pathak, P. K. (2012). Taxonomy and importance of Myrtaceae. Acta Horticulturae, 959, 23-34.

Montagut, G., Onnockx, S., Vaqué, M., Bladé, C., Blay, M., Fernández-Larrea, J., ... Pinent, M. (2010). Oligomers of grape-seed procyanidin extract activate the insulin receptor and key targets of the insulin signaling pathway differently from insulin. The Journal of Nutritional Biochemistry, 21, 476-481. http://dx.doi.org/10.1016/j.jnutbio.2009. 02.003 .

Morton, J. F. (1987). Cattley Guava. In J. F. Morton (Ed.). Fruits of warm climates (pp. 336-346). Miami, United States: Creative Resource Systems Inc.

Naczk, M., \& Shahidi, F. (2004). Extraction and analysis of phenolics in food. Journal of Chromatography A, 1054, 95-111. http://dx.doi.org/10.1016/j.chroma.2004.08.059.

Nazzaro, F., Fratianni, F., Orlando, P., \& Coppola, R. (2012). Biochemical traits, survival and biological properties of the probiotic Lactobacillus plantarum grown in the presence of prebiotic inulin and pectin as energy source. Pharmaceuticals, 5, 481-492. http://dx.doi.org/10.3390/ph5050481.

Pacheco, S. M. (2015). Frutos da família Myrtaceae: Caracterização físico-química e potencial inibitório daatividade das enzimas digestivas. Universidade Federal de Pelotas.

Patel, S. (2012). Exotic tropical plant Psidium cattleianum : A review on prospects and threats. Reviews in Environmental Science and Bio/Technology, 11, 243-248. http://dx. doi.org/10.1007/s11157-012-9269-8.

Pereira, M. C., Steffens, R. S., Jablonski, A., Hertz, P. F., Rios, De O. A., Vizzotto, M., \& Flôres, S. H. (2012). Characterization and antioxidant potential of Brazilian fruits from the Myrtaceae family. Journal of Agricultural and Food Chemistry, 60
3061-3067. http://dx.doi.org/10.1021/jf205263f.

Pino, J. A., Marbot, R. \& Vázquez, C. (2001). Characterization of volatiles in strawberry guava (Psidium cattleianum Sabine) fruit. Journal of Agricultural and Food Chemistry, 49, 5883-5887. http://dx.doi.org/10.1021/jf010414r.

Ramirez, M. R., Zanchin, N. I. T., Henriques, A. T., \& Zuanazzi, J.Â. S. (2012). Study of the effects of Psidium cattleyanum on gene expression from senescent mouse hippocampus. Boletim Latinoamericano y del Caribe de Plantas Medicinales y Aromaticas, 11, 127-137.

Raseira, M. C. B., \& Raseira, A. (1996). Contribuição ao estudo do araçazeiro, Psidium cattleyanum. Pelotas: EMBRAPA-CPACT.

Rather, M. A., Dar, B. A., Dar, M. Y., Wani, B. A., Shah, W. A., Bhat, B. A., ... Qurishi, M. A. (2012). Chemical composition, antioxidant and antibacterial activities of the leaf essential oil of Juglans regia L. and its constituents. Phytomedicine, 19, 1185-1190. http://dx.doi.org/10.1016/j.phymed.2012.07.018.

Reissig, G. N., Vergara, L. P., Franzon, R. C., Rodrigues, R. D. S., \& Chim, J. F. (2016) Bioactive compounds in conventional and no added sugars red strawberry guava (Psidium cattleianum Sabine) jellies. Revista Brasileira de Fruticultura, 38, 1-7. http:// dx.doi.org/10.1590/0100-29452016062.

Ribeiro, A. B., Chisté, R. C., Freitas, M., Da Silva, A. F., Visentainer, J. V., \& Fernandes, E. (2014). Psidium cattleianum fruit extracts are efficient in vitro scavengers of physiologically relevant reactive oxygen and nitrogen species. Food Chemistry, 165, 140-148. http://dx.doi.org/10.1016/j.foodchem.2014.05.079.

Santos, S., Lúcia, C., Petkowicz, D. O., Wosiacki, G., Nogueira, A., \& Borba, B. (2007) Caracterização do suco de araçá vermelho (Psidium cattleianum Sabine) extraído mecanicamente e tratado enzimaticamente. Acta Scientiarum. Agronomy, 29 617-621.

Shahidi, F., \& Ambigaipalan, P. (2015). Phenolics and polyphenolics in foods, beverages and spices: Antioxidant activity and health effects - A review. Journal of Functional Foods, 18, 820-897. http://dx.doi.org/10.1016/j.jff.2015.06.018.

Shay, J., Elbaz, H. A., Lee, I., Zielske, S. P., Malek, M. H., \& Hüttemann, M. (2015) Molecular mechanisms and therapeutic effects of (-)-epicatechin and other polyphenols in cancer, inflammation, diabetes, and neurodegeneration. Oxidative Medicine and Cellular Longevity, 2015. http://dx.doi.org/10.1155/2015/181260.

Silva, M. R., Santos, G. G., Mendes, D., \& Martins, D. O. (2008). Caracterização química de frutos nativos do cerrado. Ciência Rural, 38, 1790-1793.

Silva, N. A., Rodrigues, E., Mercadante, A. Z., \& Rosso, V. V. (2014). Phenolic compounds and carotenoids from four fruits native from the Brazilian Atlantic forest. Journal of Agricultural and Food Chemistry, 62, 5072-5084. http://dx.doi.org/10.1021/ jf501211p.

Sriamornsak, P. (2003). Chemistry of pectin and its pharmaceutical uses: A review. Silpakorn University International Journal, 3, 207-228. http://dx.doi.org/10.5458/jag. 54.211.

Tadera, K., Minami, Y., Takamatsu, K., \& Matsuoka, T. (2006). Inhibition of alpha-glucosidase and alpha-amylase by flavonoids. Journal of Nutritional Science and Vitaminology, 52, 149-153. http://dx.doi.org/10.3177/jnsv.52.149.

Valko, M., Leibfritz, D., Moncol, J., Cronin, M. T. D., Mazur, M., \& Telser, J. (2007). Free radicals and antioxidants in normal physiological functions and human disease. The International Journal of Biochemistry \& Cell Biology, 39, 44-84. http://dx.doi.org/10. 1016/j.biocel.2006.07.001.

Verma, A. K., Rajkumar, V., Banerjee, R., Biswas, S., \& Das, A. K. (2013). Guava (Psidium guajava L.) powder as an antioxidant dietary fibre in sheep meat nuggets. AsianAustralasian Journal of Animal Sciences, 26, 886-895. http://dx.doi.org/10.5713/ajas. 2012.12671

Vinholes, J., Gonçalves, P., Martel, F., Coimbra, M. A., \& Rocha, S. M. (2014). Assessment of the antioxidant and antiproliferative effects of sesquiterpenic compounds in in vitro Caco-2 cell models. Food Chemistry, 156, 204-211.

Vinholes, J., Lemos, G., Barbieri, R. L., Franzon, R. C., \& Vizzotto, M. (2017). In vitro assessment of the antihyperglycemic and antioxidant properties of araçá, butiá and pitanga. Food Bioscience, 19, 92-100.

Vinholes, J., Rudnitskaya, A., Gonçalves, P., Martel, F., Coimbra, M. A., \& Rocha, S. M. (2014). Hepatoprotection of sesquiterpenoids: A quantitative structure-activity relationship (QSAR) approach. Food Chemistry, 146, 78-84. http://dx.doi.org/10.1016/ j.foodchem.2013.09.039.

Vriesmann, L. C., Lúcia, C., Petkowicz, D. O., \& Borba, P. I. (2009). Acidic polysaccharide from Psidium cattleianum (Araca). Brazilian Archives of Biology and Technology, 52, 259-264. http://dx.doi.org/10.1590/S1516-89132009000200001.

Wang, W., Sun, C., Mao, L., Ma, P., Liu, F., Yang, J., \& Gao, Y. (2016). The biological activities, chemical stability, metabolism and delivery systems of quercetin: A review. Trends in Food Science \& Technology, 56, 21-38. http://dx.doi.org/10.1016/j.tifs 2016.07.004.

Wu, G. (2009). Amino acids: Metabolism, functions, and nutrition. Amino Acids, 37(1), 1-17. http://dx.doi.org/10.1007/s00726-009-0269-0. 